line and returning to our starting-point, the perpendiculars will be found pointing in a direction the opposite of that with which we started." Here then is the solution of the difficulty. As we move over our surface along a geodesic, the instantaneous Euclidian plane containing the beginnings of successive perpendiculars (for small initial portions of two successive perpendiculars to a geodesic will lie in a Euclidian plane) rotates about the instantaneous tangent to the geodesic, and it does not complete a rotation until we have travelled twice the complete length of the geodesic. The perpendicular is a vector quantity, and changes sign by passing through $\frac{l}{2} \sqrt{-I}$. Also, a geodesic does not divide the surface into two completely separate regions, as a great circle does a sphere or a straight line a plane. The two regions are continuous with one another, and it is possible to get from the one to the other along a finite path without crossing the geodesic.

Registrar-General's Office, Wellington, New Zealand, April I4

\section{Ascent of Etna}

IT was a bright sunny sky on the last day of April when we started, with Giuseppe Sedici as guide, from the Grand Hotel at Catania in a carriage and pair bound for Nicoloni, en route to the summit of Etna. A dusty drive of two and a half hours, and we were at the door of the inn in the centre of the village. Its appearance was somewhat forlorn, and its fare rather meagre, but the civility of mine host compensated for all other defects. Here we engaged two mules, a porter, and a driver, an operation which took more than two hours, and then set off again for the Casa del Bosco, which we reached in the middle of the afternoon after a ride of two and a quarter hours. A climb up a neighbouring hillock to see the sunset, dinner, and a few hours' rest filled up the time till II p.m., when we started off again and rode for about half an hour, till the appearance of snow made it necessary to dismount and continue the remainder of the journey on foot. Our guide was very slow, and on any attempt to force the pace stood still and ejaculated: "Fermo, Signore! Piano, Piano!" so that we did not arrive at the Casa Inglese till 5 a.m., and were obliged to content ourselves with seeing the sun rise from here instead of from the top, as we had intended. It did not much matter, as it was a cloudy morning, and the view was very poor, but still it was a disappointment. The Casa Inglese was covered with snow to the eaves of the roof, the observatory buried altogether, the Val del Booe a sea of white. After a short rest we trudged on again; so far it had been good walking up an easy ascent of crisp snow, but now it became a work of difficulty to pick one's way through deep drifts and treacherous-looking holes, which seemed to explain the guide's reluctance to undertake this part of the route by moonlight. Arrived however at the foot of the cone, the snow ceased, and a heavy climb up the frozen side under a biting wind began. Half way up matters were not improved by a severe attack of sickness; but at length the top was reached at $6.20 \mathrm{a} . \mathrm{m}$. There was no distant view; within the crater the steam and smoke kept being blown hither and thither, and cleared off at times sufficiently to show parts of what looked like a bottomless pit. It was a curious and weird sight altogether, and well repaid the fatigues of the journey. During the descent the notes of the cuckoo and some very sweet violets found by chance under the snow reminded us that, notwithstanding the mountain's wintry mantle of white, it was really spring time, and that the morning sun had ushered in the merry month of May, a fact which we had well nigh forgotten but a few hours before, when our fingers were numb with cold and our ears threatened to become a thing of the past.

\section{Colour Combinations}

THE production of while by red and green solutions is well seen on mixing cobalt and nickel solutions together in proper proportions. Another interesting example is that of electrically deposited copper immersed in a solution of copper sulphate. The first notice of this, so far as I know, occurs in Shaw's "Manual of Electro-Metallurgy" ( 1842$), \mathrm{p} .33$, in the following terms :-

"This phenomenon may be observed in great perfection by the electrotype ; the solution of sulphate of copper is of an intense and pure blue; and the newly precipitated ductile copper is of an equally pure orange; let the reader take a vessel containing the cupreous solution and place it in the sun, in order to have an abundance of light, and immerse in it, in a horizontal position, a piece of new electrotype copper ; immediately the metal sinks beneath the surface of the blue solution the orange tint fades, and by placing it at a proper depth altogether vanishes, and the metallic plate appears intensely white; when nicely adjusted the plate so much resembles plaster-of-paris that a person unacquainted with the nature of the experiment would with difficulty be persuaded that it was not made of that substance."

Birmingham and Midland Institute, C. J. WooDWARD June 14

P.S.-In mixing red and green solutions is it correct to speak of them as producing white? I take it that the mixture absorbs more light than the two solutions would do if separate, i.e., the solution of nickel transmits a greenish white, the cobalt solution a reddish white, but together the red and green destroy each other, the excess of white light passing through. This is shown forcibly by using strong solutions, when the deep red and green produce, not white, but black.-C. J. W.

\section{Wild Swans-Notes of Birds}

THERE are at present eight wild swans in a lake not far from here. I believe them to be part of a flock of sixty which were there all through the winter. Wild swans in summer were never, so far as I know, heard of in this part of the world before. I have always carefully preserved the wild fowl on this lake, and I pay increased attention to the swans, which I hope will be safe from poachers. They swim in pairs, but show no signs of nesting.

The major cuckoo noticed in my letter (NATURE, vol. xxii. p. 76) is still here without any other major that I could find in this place or in the neighbourhood. Referring to your polite correspondent A. N., in p. 97 , I must remark, for the fair fame of the cuckoos, that his theory relating to sex seems quite unsustainable. Certainly if all the minor cuckoos about here were males and the single major a female it would show an instance of polyandry (if the term can be applied to birds) such as could scarcely be matched in the whole range of natural history. I quite agree with Mr. Newton (p. I22) that the female cuckoo does not sing; and it might perhaps be unamiably suggested that the comparative silence of the females among the lower animals seems among the most marked distinctions between them and the human race.

Regarding Mr. Allen's letter (same page) I can only say that, while his experiences are so different from mine, there must be an imperfection of ear in either of us, and, without any notion of insisting on the correctness of my own, I should like, at least, to hear the testimony of other parties in the matter. Of course I referred to cuckoos in full voice in the height of the season. When their voice begins to decline, their notes vary, and, as a friend of mine expresses it, they "sing anyhow." Millbrook, Tuam, June 18

J. Birmingham

\section{Anchor-Ice}

Allow me to say in reply to Mr. Rae's kindly criticism (NATURE, vol. xxii. p. 54) that I did not assert that the original ice-crystals are "at least as heavy as water," but that they "seem" to be so (vol. xxii. p. 8I).

I have seen them collect upon stones at the bottom of waterways two or three feet in depth-where the stream though swift was smooth and unbroken, - and I have thought that this might be the result of their having a greater specific gravity than ordinary ice.

In my desire to be concise I had the misfortune to use a phrase that gave Mr. Rae the impression that I was asserting as a fact that which at best I have only regarded as possible.

Boston, June 7

$$
\text { C. F. C. }
$$

\section{SCIENTIFIC RESULTS OF THE HOWGATE POLAR EXPEDITION, $1877-78$}

THE fifteenth Bulletin of the United States National Museum (Washington, I879) consists of contributions to the Natural History of Arctic America, made in connection with the Howgate expedition in $1877-78$, by Ludwig Kumlien, naturalist to the expedition, who gires 